Tersedia online di: http://ejournal-balitbang.kkp.go.id/index.php/JP
e-mail:jurnalpari@gmail.com
JURNAL PARI
Volume 6 Nomor 2 Desember 2020
p-ISSN: 2502-0730
e-ISSN : 2549-0133

\title{
PEMANFAATAN E -JURNAL ILMIAH KELAUTAN DAN PERIKANAN BERBASIS OPEN JOURNAL SYSTEM PADA PEMUSTAKA PUSAT RISET PERIKANAN
}

\author{
Erny Puspa \\ Pustakawan pada Pusat Riset Perikanan \\ Diterima tanggal : 07 September 2020 Diterima setelah perbaikan : 05 Desember 2020 \\ disetujui terbit : 15 Desember 2020
}

\begin{abstract}
ABSTRAK
Tujuan penelitian untuk mengetahui pemanfaatan e-Jurnal IImiah KelautanPerikanan berbasis Open Journal System pada pemustaka Pusat Riset Perikanan. Penelitian dengan teknik pengumpulan data, observasi, kuesioner, dan studi pustaka. Sampel penelitian 32 responden pemustakadengan metode penelitian deskripsi kuantitatif. Hasil penelitian menunjukkan "baik" dalam pemanfaatannya, dapat diukur hasil analisis yaitu : $80 \%$ atau hampir seluruhnya pemustaka mengetahui keberadaan e-Jurnal IImiah KP, dan untuk pemanfaatannya sebagian besar responden (63\%) mengakses sebanyak lebih 3 kali dalam seminggu sedangkan untuk pemenuhan kebutuhan informasi sebagian besar (69\%) responden mengunjungi 4 kali lebih judul e-jurnal dengan dokumen yang diunduh dalam sebulan sebagian besar (69\%) sebanyak 10-15 dokumen. Adapun stategi pencarian informasi dan pemanfaatan yaitu sebagian besar $(69 \%)$ menyatakan melalui situs web dengan pola penelusuran sebagian besar (69\%) melalui subjek tertentu dengan kecepatan proses penelusuran hampir seluruhnya $(81 \%)$ menyatakan cepat . Dalam hal kesesuaian informasi sebagian besar $(72 \%)$ menyatakan sesuai serta $(84 \%)$ menyatakan mutakhir. Adapun dari segi ketersediaan jurnal lama kurun waktu 5-15 tahun hampir seluruhnya (81\%) menyatakan banyak tersedia Adapun dalam hal kendala sebagian besar (69 \%) responden menyatakan tidak ada kendala hanya sebagian kecil (19\%) terdapat kendala yaitu kurangnya informasi mutakhir tentang konservasi dan teknik perkapalan, dan sebagian kecil $12 \%$ menyatakan terbatasnya proses pencarian infornasi khusunya mengenai informasi mengenai bidang pengolahan dan teknologi produk karena tidak dapat ditelusuri melalui fasilitas search yang terdapat pada beranda website E- Jurnal ilmiah Kelautan dan Perikanan. Upaya yang dilakukan dalam mengatasi kendala tersebut yaitu dengan mengusulkan ke pengelola/penulis jurnal agar lebih menambah referensi up to date tentang konsevasi dan perkapalan dan untuk terbatasnya fasilitas search sebaiknya dibuat satu login sehingga dapat membuka semua lokal konten satuan kerja lain di pencarian (search) beranda e -jornal ilmiah KP tanpa membuka database satuan kerjanya
\end{abstract}

\section{Kata Kunci : e- jurnal; open journal systems; pemanfaatan; pemustaka}

\begin{abstract}
The research objective was to determine the use of the e-Journal of Marine Science andFisheries based on the Open Journal System at the Center for Fisheries Research. Research using datacollection techniques, observation, questionnaires, and literature study. The research sample was 32respondents using quantitative description research methods. The results showed \&quot;good\&quot; in its utilization, the results of the analysis can be measured, namely: $80 \%$ or almost all of the users know the existence ofthe e-Scientific Journal of KP, and for its utilization most of the respondents (63\%) access it more than 3times a week to fulfill the needs. Most of the respondents (69\%) visited the e-journal titles more than 4times with documents downloaded in a month, respondents downloaded around 10-15 documents. As for the information search and utilization strategy, most of them (69\%) stated that through web sites, most of the search patterns (69\%) were through certain subjects with the speed of the search processalmost entirely (81\%) said it was fast. In terms of conformity of the information most (72\%) stated that itwas appropriate and (84\%) stated that it was up to date. As for the availability of old journals for a periodof 5-15 years, almost all (81\%) stated that they were widely available. As for the constraints, most (69\%)of the respondents stated that there were no obstacles, only a small proportion (19\%) had
\end{abstract}

Korespondensi penulis:

Gedung BRSDM KP II, Lantai II, Jl. Pasir Putih II, Ancol Timur Jakarta Utara, 14430

email : erny.puslitbangkan@gmail.com 
problems, namely the lack of up-to-date information on conservation and shipping techniques, and a smallproportion of $12 \%$ stated that the process of seeking information, especially information regarding thefield of processing and product technology because it cannot be traced through the search facility foundon the homepage of the E-Journal of Marine and Fisheries Science Journals. Efforts made in overcoming these obstacles are by proposing journal managers / writers to add more up-to-date references about conservation and shipping and for the limited search facilities, one login should be made so that all local content of other work units can be opened in search (search) homepage. KP scientific e-journal without opening its work unit database.

\section{PENDAHULUAN}

Keywords: e-journal; open journal systems; utilization; library users

Perpustakaan khusus Pusat Riset Perikanan merupakan lembaga/unit dibawah lingkup Badan Riset Sumber Daya Manusia Kelautan dan Perikanan. Perpustakaan khususmenurut Badan Standardisasi Nasional (SNI 7496, 2009) adalah institusi/unit kerja pengelola karya tulis, karya cetak, dan karya rekam yang dikelola secara profesional berdasarkan sistem yang baku untuk mendukung kelancaran/ keberhasilanpencapaian visi, misi dan tujuan instansi induk yang menaunginya.

Pada perpustakaan khusus karya tulis ilmiah merupakan salah satu koleksi yang banyak dibutuhkan oleh pemustaka sehingga karya tulis ilmiah merupakan salah satu bahan pustaka yang layak dijadikan koleksi pada sebuah perpustakaan. Hal ini sesuai dengan Undang-Undang Republik Indonesia Nomor 43 Tahun 2007 tentang Perpustakaan dimana pada bab I pasal 1 ayat 2 disebutkan "koleksi perpustakaan adalah semua informasi dalam bentuk karya tulis, karya cetak, dan/ atau karya rekam dalam berbagai media yang mempunyai nilai pendidikan, yang dihimpun, diolah, dan dilayankan.

Demikian pula pada perpustakaan Pusat Riset Perikanan mendukung kinerja Kementerian Kelautan dan Perikanan, perpustakaan dituntut untuk dapat menyediakan sumber-sumber informasi/literatur yang relevan dengan kebutuhan pemustaka baik informasi yang diterbitkan oleh satuan kerja Badan Riset Sumber Daya Manusia Kelautan dan Perikanan (BRSDM KP) maupun literaturyang diterbitkan diluar Badan Riset Sumber Daya Manusia Kelautan dan Perikanan.

Adapun bentuk sumber informasi yang dierbitkan oleh satuan kerja Badan Riset Sumber Daya Manusia Kelautan dan Perikanan (BRSDM KP) merupakankarya/hasil penelitian ilmiah yang memuat informasi tentang kebijakan/Peraturan, budidaya, penangkapan, sumberdaya, konservasi, sosial ekonomi, kelautan, paska panen dan pengolahan produk kelautan dan perikanan yang dikelola dan diterbitkan secara tercetak dalam bentuk jurnal, prosiding, buletin maupun warta.
Seiring dengan perkembangan teknologi informasi, pada tahun 2015 pengelolaan penerbitan jurnal BRSDM dari yang tercetak beralih dikelola secara online/elektronik menggunakan perangkat Open Journal System (OJS).Open Journal Systems (ojs) merupakan perangkat lunak yang mendukung pengaturan dan penerbitan jurnal ilmiah secara online dan di-desain sebagai sistem multi jurnal yang dapat digunakan untuk mengelola sejumlah jurnal dalam sebuah instalasi tunggal (Kementerian Pendidikan dan Kebudayaan Indonesia, 2012). Dengan beralihnya pengelolaan dan pemanfaatan jurnal ilmiah kelautan dan perikanan secara elektronik melalui OJS dapat memberi manfaat bagi perpustakaan Pusat Riset Perikanan, seperti: bertambahnya koleksi perpustakaan secara online, memudahkan penelusuran informasi secara cepat dan tepat, dapat menjadi sumber informasi sebagai kemas ulang informasi, penelusuran informasi tanpa batasan tempat, ruang dan waktu yang dapat diakses melalui website http://e.journal.balitbang.kkp.go.id.

Berkaitan dengan latar belakang diatas, penulis tertarik untuk meneliti terkait pemanfaatan e-Jurnal IImiah Kelautan dan Perikanan (e-Jurnal IImiah KP) berbasis Open Journal System (OJS) pada pemustaka Pusat Riset Perikanan dengan tujuan agar mengetahui pemanfaatan e jurnal dan kendala yang dihadapi dan upaya mengatasinya.

\section{TINJAUAN LITERATUR Jurnal}

Menurut Adnan (2005) menyebutkan jurnal ilmiah sebagai forum komunikasi bagi anggota masyarakat ilmiah disiplin ilmu tertentu

Basuki (1996) mengatakan bahwa jurnal (majalah ilmiah) adalah terbitan yang muncul dalam frekuensi teratur untuk jangka waktu yang tidak ditentukan berisi artikel atau pejelasan sebuah teori atau hasil penelitian atau penerapan sebuah teori dan setiap kali terbit paling sedikit memuat tiga artikel. Sedangkanmenurut Lasajurnal adalah terbitan dalam bidang tertentu oleh instansi, badan organisasi profesi maupun lembaga keilmuan. Terbit secara berkala dan teratur berisi informasi ilmiah, hasil penelitian, 
prosiding seminar maupun pertemuan ilmiah lain dan hal ini senada dengan pendapat Hakim (2012) jurnal ilmiah adalah "majalah publikasi yang memuat KTI (karya tulis ilmiah) yang secara nyata mengandung data dan informasi yang mengajukan iptek dan ditulis sesuai dengan kaidah-kaidah penulisan ilmiah serta diterbitkan secara berkala".

Dari definisi definisi diatas dapat disimpulkan jurnal imiah merupakan terbitan secara berkala yang berisi tulisan/ artikel imilah yang diterbitkan oleh instansi atau badan organisasi tertentu yang ditulis dengan kaidah kaidah ilmiah.

Adapun kaidah karya tulis ilmiah terdiri atas sifat berikut (LIPI, 2012) 1. Logis, berarti berunutan penjelasan dari data dan informasi yang masuk ke dalam logika pemikiran kebenaran ilmu. 2. Obyektif, berarti data dan informasi sesuai dengan fakta kebenarannya. 3. Sistematis, berarti sumber data dan informasi yang diperoleh dari hasil kajian dengan mengikuti urutan pola pikir yang sistematis atau litbang yang konsisten/berkelanjutan. 4. Andal, berarti data dan informasi yang telah teruji dan sahih serta masih memungkinkan untuk terus dikaji ulang. 5 . Desain, berarti terencanakan dan memiliki rancangan, dan 6. Akumulatif, berarti kumpulan dari berbagai sumber yang diakui kebenaran dan keberadaannya serta memberikan kontribusi bagi khasanah iptek yang sedang berkembang

\section{Pemustaka}

Menurut Undang-Undang Nomor 43 Tahun 2007 pasal 1 ayat 9 pemustaka adalah pengguna perpustakaan, yaitu perseorangan, kelompok orang, masyarakat, atau lembaga yang memanfaatkan fasilitas layanan perpustakaan, sedangkan menurut Suwarno (2009), pemustaka adalah pengguna fasilitas yang disediakan perpustakaan baik koleksi maupun buku (bahan pustaka maupun fasilitas lainnya). Sedangkan Sutarno (2008), mendefinisikan pemakai perpustakaan adalah responden atau kelompok masyarakat yang memakai dan memanfaatkan layanan perpustakaan, baik anggota maupun bukan anggota. Berdasarkan pengertian tersebut, dapat disimpulkan bahwa pemustaka adalah pengguna perpustakaan baik anggota maupun bukan anggota perpustakaanyang memanfaatkan layanan, fasilitas, jasa dan koleksi yang tersedia di perpustakaan baik koleksi digital maupun koleksi cetak

\section{Jurnal Elektronik}

Menurut LIPI (2005), “Jurnal elektonik (e-jurnal) adalah sarana berbasis web untuk mengelola sebuah jumal ilmiah maupun non ilmiah. Sarana ini disediakan sebagai wadah bagi pengelola, penulis dan pembaca karya-karya ilmiah.

E-journal adalah publikasi dalam format elektronik dan mempunyai ISSN (International Standard Serial Number). Melalui e-journal, beberapa proses penerbitan seperti pengumuman, permintaan naskah, pengiriman naskah, review, pemberitahuan hasil review, pengiriman perbaikan naskah, pengeditan dan layout, pencetakan, serta distribusi dilakukan secara online. Sehingga semua dapat dilakukan secara cepat, proses penerbitan bagi pengelola lebih cepat, biaya penerbitan dan pengelolaan murah, distribusi cepat dan murah.

\section{Open Journal System (OJS)}

Asal mula Open Journal System. Sistem ini perama kali dimunculkan pada tahun 2002 pada saat penelitian dan perkembangan inisiatif Public Knowledge Project di University of British Columbia, dengan dukungan dari ilmu sosial dan Lembaga Penelitian Masyarakat Kanada, Max Bell Foundation, Pacific Press Endownment, dan Mac Arthur Foundation. Perkembangan berkalanya ditandai dengan kerjasama ntara UBC's Public Knowledge Project, the Canadian Center for Studies in Publishing dan Simon Fraer University Library.http:// raghibnuruddin237.blogspot.com/2013/01/pengertianopen-journal-system.html.

Pengertian OJS menurut buku panduan pengelolaan terbitan berkala E-journalmenyebutkan bahwa Open Journal Systems merupakan perangkat lunak yang mendukung pengaturan dan penerbitan jurnal ilmiah secara online dan di-desain sebagai sistem multi jurnal yang dapat digunakan untuk mengelola sejumlah jurnal dalam sebuah instalasi tunggal (Kementerian Pendidikan dan Kebudayaan Indonesia, 2012). Sedangkan menurut Leptin(2012) OJS merupakan akses terbuka(openaccess)telah meningkatkan momentum untuk sebuah model penerbitan ilmiah memungkinkan hasil penelitian dapat diakses gratis oleh komunitas dan dapat diakses secara publik di internet.

OJS dirancang khusus untuk mempermudah manajemen jurnal secara online dimulai dari proses pengeditan, hingga publikasi. Bahkan OJS dilengkapi dengan fitur untuk melihat record dari jurnal yang diterbitkan. OJS juga membantu meningkatkan kualitas penerbitan jurnal dengan berbagai inovasi dan fungsi-fungsi untuk meningkatkan transparansi publikasi dan review hingga meningkatkan indeksasi jurnal, Handoko (2017). 
Berdasarkan dari beberapa pendapat yang dikemukakan diatas, maka dapat disimpulkan bahwa "Open Journal System (OJS) Open Journal System (OJS) adalah sistem /aplikasi elektronik untuk pengeloaan jurnal ilmiah dari proses awal (editing) hingga menjadi dokumen yang siap dipublikasikan melaui website dan mudah diakses publik

Manfaat OJS bagi perpustakaan :

1. Banyak tersedia dokumentasi

2. Penelusuran informasi yang cepat dan tepat tanpa mengenal tempat dan waktu

3. Dapat diakses full teks secara mudah
4. Dapat ditelusur melalui subjek, judul dan pengarang

5. Memuat dokumentasi yan lama dan data yg mutakhir

6. Menjadi sumber jasa penelusauran

7. Dapat menjadi sumber pembuatan kemas ulang informasi

Dalam tinjauan literatur diatas dapat diketahui perbedaan jurnal yang dikelola secara tercetak dan secara elektronik, sehingga dapat diketahui kelebihan dan kekurangannya yang dapat dilihat pada tabel 1 sebagai berikut:

Tabel 1. Kelebihan dan kekurangan jurnal elektronik dan jurnal tercetak (Tresnawan, 2005)

\begin{tabular}{clll}
\hline No & Kriteria & Elektronik & Tercetak \\
\hline 1 & Kemuktahiran & Mutakhir & Mutakhir \\
2 & Kecepatan diterima & Cepat & Lambat \\
3 & Penyimpanan & Sangat mengirit tempat & Makan Tempat \\
4 & Pemanfaatan & 24 Jam & Terbatas jam buka \\
5 & Kesempatan akses & Bisa bersamaan & Antri \\
6 & Penelusuran & Otomatis tersedia & Harus dibuat \\
7 & Waktu penelusuran & Cepat & Lama \\
8 & Keamanan & Lebih aman & Kurang aman \\
9 & Manipulasi dokumen & Sangat mudah & Tidak bias \\
10 & Langganan harga yang sama & Judul bisa lebih banyak & Judul lebih sedikit \\
11 & Harga total langganan & Jauh lebih murah & Lebih mahal \\
\hline
\end{tabular}

\section{METODE PENELITIAN}

Metode penelitian menggunakan deskriptif kuantitatif, data diperoleh dari hasil observasi, studi pustaka dan penyebaran kuiesioner. Subyek penelitian adalah 40 pemustaka yang berkunjung ke perpustakaan. Sampel diambil sebanyak 40 responden yang terdiri 27 mahasiswa, 8 peneliti dan 5 karyawan sebagaimana Arikunto (2002, hlm. 112) mengemukakan bahwa jika subjeknya kurang dari 100 lebih baik diambil semua sehingga penelitian merupakan penelitian populasi. Jika jumlahnya besar dapat diambil $10-15 \%$ atau $20-25 \%$. Teknik pengambilan sampel dilakukan melalui teknik accidental. Data kuantitatif kemudian diolah dan ditentukan secara persentase Sudijono (1991, hlm.40) dengan rumus rumus sebagai berikut:<smiles>N#[Y20][Na]</smiles>

Keterangan:

$\mathrm{P}=$ Persentase

$\mathrm{F}=$ Frekuensi Jawaban Responden

$\mathrm{N}$ = Sampel yang diolah
Penafsiran data dilakukan dengan menggunakan pedoman penafsiran data sebagaimana dikemukakan oleh Arikunto (2010) sbb :

$\begin{array}{ll}1 \%-25 \% & : \text { Sebagian kecil } \\ 26 \%-49 \% & : \text { : } \text { Sampir separuhnya } \\ 50 \% & : \text { Sebaruhnya } \\ 51 \%-75 \% & : \text { Hampian besar } \\ 76 \%-99 \% & : \text { Seluruhnnya } \\ 100 \% & \end{array}$

\section{HASIL DAN PEMBAHASAN}

Hasil dari evaluasi kemanfaatan e- jurnal ilmiah KP berbasi ojs dapat diketahui dari hasil jawaban responden dari data kuesioner terdiri beberapa variabel

I. Pengenalan E Jurnal IImiah KP berbasis OJS

II. Pengaksesan E Jurnal IImiah KP berbasis OJS

III. Strategi dan cara Pemanfaatan E Jurnal berbasis OJS

IV. Keberadaan dan Kesesuaian Informasi

V. kendala yang dihadapi 


\section{Pengenalan E Jurnal IImiah Kelautan dan Perikanan berbasis OJS}

Dalam hal ini pemustaka (responden) perpustakaan Pusriskan ada yang sudah mengetahui dan ada yang belum mengetahui jurnal ilmiah KP yang terdapat pada website e.journal.balitbang.kkp.go.id. hal ini dapat diketahui dari 40 kuesioner yang dibagikan 32 responden (80\%) menyatakan 'mengetahui dan sebanyak 8 responden (20\%) menyatakan tidak mengetahui adanya E.jurnal ilmiah KP berbasis OJS

\section{Pengaksesan E Jurnal IImiah KP Berbasis OJS}

Dalam pengaksesan e -Jurnal, data kuesioner meliputi sub variabel:

\section{Frekuensi pengaksesan e.jurnal KP dalam satu minggu}

Frekuensi pengaksesan e-Jurnal IImiah KP dapat menunjukkan seberapa tingkatan pemanfaatan ejurnal oleh pemustaka. Frekuensi pengaksesan ejurnal ilmiah KP dapat dilihat pada data sebagai berikut: responden yang menyatakan 1 kali sebanyak 2 responden $(6 \%)$, menyatakan 2 kali sebanyak 3 responden $(9 \%)$, menyatakan 3 kali sebanyak 7 responden (22\%) dan menyatakan sebanyak lebih 3 kalisebanyak 20 responden $\left(63 \%_{\text {; }}\right)$.

\section{Frekuensi Kunjungan e- Jurnal ilmiah KP Berbasis OJS}

Dalam hal pemenuhan kebutuhan informasi, responden yang menyatakan mengunjungi judul eJurnal IImiah KP yaitu: 1 judul jurnal sebanyak 0 responden ( $0 \%)$, mengunjungi 2 judul jurnal sebanyak 4 responden (12\%), mengunjungi sebanyak 3 judul jurnal 6 responden (19\%), dan mengunjungi lebih 4 judul jurnal sebanyak 22 responden $(69, \%)$.

\section{Besaran Pengaksesan Yang Diunduh}

Besarnya pengaksesan pada e-Jurnal IImiah KP berpengaruh pada jumlah dokumen yang diunduh sebulan. Dari data hasil kuesioner dapat diketahui dokumen yang diunduh padae-Jurnal IImiah KP dalam sebulan yaitu 1 s.d 5 dokumen sebanyak 3 responden $(9 \%)$, yang menyatakan mengunduh 5 s.d 10 dokumen sebanyak 7 responden (22\%), dan yang menyatakan mengunduh 10 s.d 15 dokumen sebanyak 22 responden (69\%).

\section{Strategi dan cara Pemanfaatan E Jurnal}

Dalam strategi dan cara pemanfaatan e-Jurnal IImiah KP, data kuesioner meliputi sub variabel:

\section{Strategi Penelusuran}

Diperlukan strategi agar mendapatkan kemudahan dalam penelusuran informasi. Dalam hal ini diperlukan kemampuan pemustaka dalam strategi pencarian di internet. Sebagaimana Pendit (2008) 'Di bidang perpustakaan dan informasi, keberaksaraan informasi ini segera dikaitkan dengan kemampuan mengakses dan memanfaatkan secara benar sejumlah informasi yang tersedia di Internet. Hal yang perlu diperhatikan dalam memanfaatkan teknologi internet ini pengguna (user) diharapkan memiliki pengetahuan atau ketrampilan dalam menelusur informasi serta mengetahui strategi penelusuran agar dalam penelusuran bisa lebih efektif dan efisien.

Dalam strategi penelusuran informasi pada E Jurnal Imiah KP , dari hasil data kuesioner dapat diketahui responden yang menyatakan strategi untuk pencarian informasi e- Jurnal Ilmiah KP secara langsung ke situs web sebanyak 22 responden (69\%), menyatakan langsung ke data base sebanyak 2 responden (6\%),dan menyatakan langsung melalui search engine sebanyak 8 responden (25\%).

\section{Pola Penelusuran Digunakan}

Berdasarkan hasil kuesioner dapat diketahui bahwa pola penelusuran yang dilakukan dalam pencarian informasi pada e-Jurnal IImiah KP secara cepat, benar dan relevan adalah melalui judul sebanyak 1 responden (3\%), menyatakan melalui pengarang 9 responden $(28,13 \%)$, menyatakan melalui subjek tertentu 22 responden $(69 \%$.

\section{Kecepatan Proses Penelusuran}

Berdasarkan hasil kuesioner dapat diketahui bahwa dalam penelusuran proses kecepatan penerimaan data sampai ke databaseadalahrespondenyang menyatakan cepat sebanyak 26 responden (81\%), yang menyatakan sedang 6 responden (19\%), menyatakan lambat 0 responden dan menyatakan sangat lambat 0 responden $(0 \%)$.

\section{Kesesuaian Informasi}

Dalam kesesuaian Informasi, data perolehan kuesioner meliputi sub variabel : 


\section{Kesesuaian Informasi Yang Diperoleh}

Berdasarkan hasil kusioner responden yang menyatakan data base pada e-Jurnal IImiah KP sudah sesuai kebutuhan informasinya, sebanyak 7 responden (22\%) menyatakan sangat sesuai dan 23 responden $(72 \%)$ menyatakan sesuai, yang menyatakan kurang sesuai 2 responden $(6 \%)$, yang menyatakan tidak sesuai 0 responden $(0 \%)$.

\section{Kemutakhiran Jurnal}

Berdasarkan hasil kusioner dapat diketahui responden yang menyatakan informasi e-Jurnal IImiah KP selalu mutakhir, sebanyak 26 responden (84\%), dan menyatakan tidak mutakhir 6 responden (16\%).

\section{Ketersediaan Jurnal Lama}

Dalam hal Ketersediaan jurnal lama rentang usia 5-15 tahun pada E jurnal KP, responden yang menyatakan kurang tersedia sebanyak 6 responden (19\%) dan yang menyatakan banyak tersedia sebanyak 26 responden (81\%)

\section{Kendala Yang Dihadapi}

Berdasarkan hasil data kuesioner dapat diketahui bahwa permasalahan kendala yang dihadapi pemustaka dalam memanfaatkan e-Jurnal, responden yang menyatakan kurang mengetahui teknis penggunaannya 0 responden $(0 \%)$, yang menyatakan kurangnya mendapatkan topik yang sesuai sebanyak 6 responden (19\%), menyatakan penggunaan terbatas responden $(12 \%)$ dan yang menyatakan tidak ada kesulitan 22 responden ( $69 \%$ ).

Tabel 2. Rekapitulasi Pemanfaatan E -Jurnal IImiah Kelautan dan Perikanan Berbasis OJS Pada Pemustaka Pusat Riset Perikanan

\begin{tabular}{|c|c|c|c|c|c|}
\hline No. & Variabel & Hal & Jawaban Terbanyak & $\begin{array}{c}\text { Jumlah } \\
\text { Responden }\end{array}$ & $\begin{array}{c}\text { Persentas } \\
(\%)\end{array}$ \\
\hline 1 & Pengenalan E -Journal KP & Mengetahui adanya e Jurnal IImiah KP & mengetahui & 32 & $80 \%$ \\
\hline \multirow[t]{3}{*}{2} & Pengaksesan E- journal & $\begin{array}{l}\text { Frekuensi pengaksesan e.jurnal KP } \\
\text { dalam satu minggu }\end{array}$ & $\begin{array}{l}\text { mengakses lebih } 3 \text { kali dalam } \\
\text { seminggu }\end{array}$ & 20 & $63 \%$ \\
\hline & & $\begin{array}{l}\text { Frekuensi Kunjungan E- Jurnal untk } \\
\text { memenuhi kebutuhan informasi }\end{array}$ & $\begin{array}{l}\text { mengunjungi lebih } 4 \text { E-Jurnal } \\
\text { IImiah KP }\end{array}$ & 22 & $69 \%$ \\
\hline & & $\begin{array}{l}\text { Besaran literatur yang diunduh dalam } \\
\text { 1bulan }\end{array}$ & sebanyak $10-15$ dokumen & 22 & $69 \%$ \\
\hline \multirow[t]{3}{*}{3} & Strategi /cara Penulusuran & Cara penelusuran & melalui situs web. & 22 & $69 \%$ \\
\hline & & Pola Penelusuran Digunakan & $\begin{array}{l}\text { melalui subjek tertentu/kata } \\
\text { kunci }\end{array}$ & 22 & $69 \%$ \\
\hline & & Kecepatan Proses Penelusuran & Cepat & 26 & $81 \%$ \\
\hline \multirow[t]{3}{*}{4} & Kesesuaian informasi & Kesesuaian Informasi Yang Diperoleh & sesuai & 23 & $72 \%$ \\
\hline & & Kemutakhiran informasi & mutakhir & 23 & $84 \%$ \\
\hline & & Ketersediaan Jurnal lama & banyak tesedia & 26 & $81 \%$ \\
\hline 5 & Kendala & Terdapat kendala dalam proses & & 22 & $69 \%$ \\
\hline
\end{tabular}

\section{Analisa Penelitian}

Dari hasil rekapitulasi pemanfaatan E -Jurnal IImiah Kelautan dan Perikanan berbasis OJS pada pemustaka Pusat Riset Perikanan dapat dianalisa bahwa dalam hal pengenalan E- Jurnal IImiah KP dapat diketahui hampir seluruhnya 32 responden (80\%) pemustaka sudah mengetahui adanya e jurnal ilmiah $\mathrm{KP}$, namun tidak semua pemustaka mengetahui adanya e- jurnal ilmiah KP ini, dikarenakan dari 40 kuesioner yang dibagikan terdapat 8 responden yang tidak mengisi dan mengembalikan kuesioner tersebut dengan alasan tidak mengetahui adanya e- jurnal ilmiah KP. Dalam hal ini perlu dilakukan promosi dan sosialisasi terhadap pemustaka yang datang karena tidak semua pemustaka yang datang mengetahui adanya e jurnal KP berbasis ojs ini, dengan tujuan e -jurnal IImiah KP dapat dikenal dan dapat dimanfaatkan semaksimal mungkin.

Adapun Frekuensi pengaksesan e.jurnal KP dalam satu minggu sebagian besar 20 responden (63\%) menyatakan mengakses lebih 3 kali dalam seminggu dengan frekuensi kunjungan jurnal sebagian besar 22 responden (69\%) menyatakan mengunjungi lebih 4 judul e-Jurnal IImiah KP dan sebagian besar 22 
responden $69 \%$ menyatakan dokumen yang diunduh dalam sebulan sebanyak 10-15 dokumen. Kunjungan lebih 4 Judul merupakan jawaban yang teringgi dan hal ini merupakan sepatutnya karena pada e jurnal ilmiah KP berbasis OJS memiliki beberapa judul jurnal yang dapat dikunjungi (lihat lampiran 1).

Dalam hal strategi penelusuran ke e-jurnal ilmiah KP sebagian besar 22 responden (69\%) menyatakan informasi e-Jurnal IImiah KP didapatkan melalui situs web. Strategi pencarian informasi melalui web memang mempermudah dalam pencarian sumber informasi/ artikel sebagaimana Mubarok (2018) "Manfaat website untuk masyarakat yang pertama adalah sebagai sumber informasi. Di era digital ini, masyarakat menghabiskan sebagian besar waktunya di dunia maya. Salah satu aktivitas yang paling banyak dilakukan masyarakat Indonesia adalah membaca artikel.Manfaat website untuk masyarakat yang kedua adalah untuk mengakses layanan publik. di era digital ini, layanan publik pun sudah mulai banyak tersedia melalui website".

Pola penelusuran merupakan cara proses temu kembali informasi untuk mendapatkan inormasi yang dibutuhkan secara cepat, tepat dan benar. Sebagaimana Basuki(1992). "Temu balik informasi" merupakan istilah yang mengacu pada temu balik dokumen atau sumber atau data dari fakta yang dimiliki unit informasi atau perpustakan. Sedangkan penelusuran informasi merupakan bagian dari sebuah proses temu kembali informasi yang dilakukan untuk memenuhi kebutuhan pemakai akan informasi yang dibutuhkan, dengan bantuan berbagai alat penelusuran dan temu kembali informasi yang dimiliki perpustakaan/ unit informasi. Adapun pola penelusuran responden pada e-Jurnal IImiah KP sebagian besar 22 responden (69\%) menyatakan melalui subjek tertentu/kata kunci tertentu. Hal ini sebagaimana dinyatakan oleh Zaharnita (2016). bahwa internet merupakan sumber belajar alternatif yang cukup efektif dan efisien karena internet menyediakan berbagai informasi yang tak terbatas dan mumberikan kemudahan pencarian hanya dengan mengetik kata kunci dari materi pembelajaran yang akandicari.

Dalam hal kecepatan dalam penelusuran hampir seluruhnya 26 responden ( $81 \%$ ) menyatakan proses penelusuran cepat dalam hal ini menunjukkan hal yang baik bagi pemanfaatan e jurnal ilmiah KP.

Sedangkan kesesuaian informasi yang diperoleh sebagian besar 23 responden (72\%) menyatakan sesuai. Adapun kemutakhiran informasi pada e- jurnal ilmah KP hampir seluruhnya 27 responden (84\%) menyatakan mutakhir. Untuk ketersediaan jurnal lama rentang usia 5-15 tahun pada e- jurnal ilmiah KP hampir seluruhnya 26 responden $(81 \%)$ banyak tersedia. Hal ini sesuai dengan ketentuan naskah yang akan diterbitkan ke dalam jurnal terbitan Pusat Riset Perikanan "bahwa referensi naskah yang masuk harus mengandung pustaka referensi yang berasal dari sumber primer (jurnal ilmiah dan berjumlah minimal $50 \%$ dari total yang tercantum di bawah) yang diterbitkan 10 (sepuluh) tahun" ( publication ethics E Jurnal. Kkp. go.id).

Dalam hal kendala kepemanfaatan e- jurnal ilmiah KP pada sebagian besar 22 responden (69\%) menyatakan tidak ada kendala/kesulitan dalam proses pemanfaatan e-Jurnal IImiahKP, hal ini dapat dinyatakan baik bagi pemanfaatan ejurnal ilmiah KP di http://ejournal-balitbang.kkp.go.id/. , namun masih terdapat permasalahan yaitu sebagian kecil 6 responden $19 \%$ menyatakan kurangnya topik up to date perihal subjek konservasi dan teknik perkapalan dalam hal ini sebagai pustakawan akan menyampaikan ke bagian redaksi selaku pengelola naskah jurnal agar menindaklanjut hal tersebut, dan juga terdapat sebagian kecil 4 responden (12\%) menyatakan perihal penggunaan terbatas (12\%) adalah untuk pencarian informasi dari jurnal yang diterbitkan pengolahan produk dan bioteknologi karena belum link dengan website pada .jurnal ilmiah KP berbasis ojs ini sehingga tidak bisa di search melaui beranda E Jurnal IImiah Kelautan dan Perikanan karena harus mebuka dulu data base jurnal terbitan pengolahan produk dan bioteknologi sehingga dirasa kurang efisien

\section{KESIMPULAN}

Tujuan dari tulisan ini adalah dapat mengevaluasi tingkat pemanfaatan e jurnal ilmiah KP berbasis ojs pada pustakawan Pusat Riset Perikanan. Hasil dari penelitian ini dapat diukur dari analisa penelitian yang diuraikan diatas dapat dapat diperoleh kesimpulan sebagai berikut : $80 \%$ atau hampir seluruhnya pemustaka mengenal/ mengetahui e-Jurnal IImiah KP dimana dalam pemanfaatannya sebagian besar responden (63\%) mengakses sebanyak lebih dari 3 kali dalam seminggu dan untuk pemenuhan kebutuhan informasi sebagian besar (69\%) responden mengunjungi lebih 4 kali judul e Jurnal ilmiah KP dengan dokumen yang diunduh dalam sebulan sebagian besar (69\%) sebanyak 10-15 dokumen. Adapun strategi pencarian informasi dan pemanfaatan pada e-jurnal ilmiah KP sebagian besar (69\%) menyatakan melalui situs web dengan pola penelusuran sebagian besar(69\%) melalui subjek tertentu dengan kecepatan proses penelusuran hampir seluruhnya (81\%) menyatakan cepat. Dalam 
kesesuaian informasi yang diperoleh sebagian besar (72 \%) menyatakan sesuai serta (84\%) responden menyatakan mutakhir. Adapun dari segi ketersediaan informasi e jurnal lama rentang waktu 5-15 tahun hampir seluruhnya (81\%) responden menyatakan banyak tersedia. Adapun dalam hal kendala sebagian besar (69\%) responden menyatakan tidak ada kendala hanya sebagian kecil $(19 \%)$ menyatakan terdapat kendala yaitu kurangnya mendapatkan inforrmasi up to date tentang subjek konservasi dan teknik perkapalan, dan(12\%) menyatakan terbatasnya proses pencarian infornasi khusunya mengenai informasi mengenai bidang pengolahan dan teknologi produk perikanan karena tidak dapat ditelusuri melaui fasilitas search yang terdapat pada beranda website e-journal- balitbang.kkp.go.id.

\section{SARAN}

1. Dalam hal pengenalan terhadap e-Jurnal IImiah KP terdapat $20 \%$ yang belum mengetahui keberadaan e-Jurnal. Adapun upaya yang dilakukan dengan memberi informasi dan sosialisasi terhadap pemustaka yang berkunjung ke perpustakaan sehinggakeberadaan e-Jurnal IImiahKP/website: ejurnal-balitbang.kkp.go.id dapat lebih dikenal dan banyak dimanfaatkan

2. Agar kesesuaian dan terkaitan kemutahiran koleksi (selalu up to date) sesuai dengan kebutuhan informasi pemustaka sebaiknya pustakawan/petugas perpustakaan menyampaikan pada pengelola keredaksian ejournal agar dapat menindak lanjuti perihal referensi terkait dengan konservasi dan teknik kapal

3. Dalam pengaksesan penelusuran agar dibuat satu login sehingga dapat membuka semua lokal konten satuan kerja lain di pencarian (search) beranda e -jornal ilmiah KP tanpa membuka database satuan kerjanya

\section{DAFTAR PUSTAKA}

Adnan, Z dan I Zifirdaus. 2005. Meraih Hati Audiens Internasional:Strategi Ampuh Meraih Publikasi di Jurnal Ilmiah. Jakarta: Gramedia

Arikunto, S., 2002. Prosedur Penelitian, Suatu Pendekatan Praktek, Jakarta : PT Rineka Cipta

Arikunto, S. 2010. Prosedur Penelitian Suatu Pendekatan Praktik. Jakarta: Rineka Cipta.

Basuki, Sulistiyo.1992. Pengantar IImu Perpustakaan. Jakarta: Gramedia Pustaka Utama

Basuki, Sulistiyo 1996. Pengantar IImu Perpustakaan. Jakarta: Gramedia Pustaka Utama
Handoko, Arief, Ikhawan,Yuhefizar, 2017. Kupas Tuntas Open Journal System. Jakarta: PT Elex Media Komputindo. 2017. Kupas Tuntas Open Journal System. Jakarta: PT Elex Media Komputindo.

Hasan, Thamrin, 2013. Kajian Pemanfaatan Jurnal Online Pada perpustakaan Universitas Riau Pekanbaru, Pekabaru: Jurnal Gema Pustakawan, Vol.1, No.1. Mei 2013.

Indonesia. Badan Standar Nasional RI, 2009, Standardisasi nasional Indonesia untuk perpustakaan khusus instansi pemerintah, Perpustakaan Nasional RI, Jakarta.

Indonesia. Undang-Undang Perpustakaan Republik Indonesia Nomor 43 Tahun 2007 tentang perpustakaan. Dalam www.Menpan.go.id,/ diakses. 5 September 2020

Jamaluddin, K. 2015. Mengenal Elektronik Jurnal dan Manfaatnya Bagi Pengembangan Karier Pustakawan. Jupiter .http://journal.unhas.ac.id/ index.php/jupiter/article/view/36 diakses 23 Juni 2020

Indonesia. Kementerian Pendidikan dan Kebudayaan Indonesia, (2012 Panduan Pengelolaan Jurnal Terbitan Berkala Elektonik. diunduh dari http:// www.dikti.go.id/files/atur/PanduanPengelolaaneJournal.pdf, / diakses 5 februari 2020

Indonesia, Lembaga IImu Pengetahuan Indonesia .2012. Pedoman Karya Tulis IImiah. LIPI: Jakarta

Indonesia. Lembaga IImu Pengetahuan Indonesia. 2005. Jurnal Online. Retrieved December 23, 2012, from http://www.jurnaLlipi.go.id/utama/diakses 5 November 2020

Leptin, M. (2012). Editorial: Open access: Pass the buck. Science, 355(6074), 1279

Mubarok,Ilham.2018. Manfaat Website untuk Pribadi, Bisnis, dan Masyarakat.https:// www.niagahoster.co.id/blog/manfaat-website/ diakses 3 Maret 2020

Pendit, Putu Laxman, (2008) Perpustakaan digital dari A sampai Z, Jakarta, Cita Karyakarsa Mandiri

Zaharnita, E., Witarsa, Rosyid, R. (2016) Pemanfaatan internet sebagai sumber informasi belajar pada mahasiswa pendidikan ekonomi universitas tanjungpura. www.Jurnal.untan.ac.id.Diakses 22 Agustus 2020. 
Lampiran 1. Tabel 3. Daftar Publikasi Pada E-Jurnal IImiahKP

\begin{tabular}{|c|c|c|c|}
\hline No & Nama Jurnal & Penerbit & ISSN \\
\hline 1 & Jurnal Penelitian Perikanan Indonesia & Pusat Riset Perikanan & $\begin{array}{l}\text { p-ISSN 0853-5884; } \\
\text { e-ISSN 2502-6542 }\end{array}$ \\
\hline 2 & Indonesian Fisheries Research Journal & Pusat Riset Perikanan & $\begin{array}{l}\text { p-ISSN 0853-8980; } \\
\text { e-ISSN 2502-6569 }\end{array}$ \\
\hline 3 & Jurnal Kebijakan Perikanan Indonesia & Pusat Riset Perikanan & $\begin{array}{l}\text { p-ISSN 1979-6366; } \\
\text { e-ISSN 2502-6550 }\end{array}$ \\
\hline 4 & Bawal Widya Riset Perikanan Tangkap & Pusat Riset Perikanan & $\begin{array}{l}\text { p-ISSN 1907-8226; } \\
\text { e-ISSN 2502-6410 }\end{array}$ \\
\hline 5 & $\begin{array}{l}\text { Buletin Teknik Litkayasa Sumber Daya } \\
\text { Dan Penangkapan }\end{array}$ & Pusat Riset Perikanan & \\
\hline 6 & Jurnal Riset Akuakultur & Pusat Riset Perikanan & $\begin{array}{l}\text { p-ISSN 1907-6754; } \\
\text { e-ISSN 2502-65 }\end{array}$ \\
\hline 7 & Indonesian AquaculturE Jurnal & Pusat Riset Perikanan & $\begin{array}{l}\text { (p-ISSN 0215-0883 } \\
(e-I S S N ~ 2502-6577)\end{array}$ \\
\hline 8 & Media Akuakultur & Pusat Riset Perikanan & $\begin{array}{l}\text { p-ISSN 1907-6762; } \\
\text { e-ISSN 2502-9460) }\end{array}$ \\
\hline 9 & Buletin Teknik Litkayasa Akuakultur & Pusat Riset Perikanan & $\begin{array}{l}\text { p-ISSN 1412- } \\
9574 \text { dan E- } \\
\text { ISSN 2541-2442 }\end{array}$ \\
\hline 10 & $\begin{array}{l}\text { Squalen Bulletin Of Marine And Fisheries } \\
\text { Postharvest And Biotechnology }\end{array}$ & $\begin{array}{l}\text { Balai Besar Riset } \\
\text { Pengolahan Produk dan } \\
\text { Bioteknologi Kelautan dan } \\
\text { Perikanan }\end{array}$ & $\begin{array}{l}\text { p ISSN: } 2089-5690 \\
\text { E-ISSN 2406-9272 }\end{array}$ \\
\hline 11 & $\begin{array}{l}\text { Jurnal Pascapanen Dan Bioteknologi } \\
\text { Kelautan Dan Perikanan }\end{array}$ & $\begin{array}{l}\text { Balai Besar Riset } \\
\text { Pengolahan Produk dan } \\
\text { Bioteknologi Kelautan dan } \\
\text { Perikanan }\end{array}$ & $\begin{array}{l}\text { ISSN: } 2406- \\
9272 \text { (online) }\end{array}$ \\
\hline 12 & Jurnal SEGARA & Pusat Riset Kelautan & $\begin{array}{l}\text { p-ISSN: } 1907-0659 \\
\text { e-ISSN: } 2461-1166\end{array}$ \\
\hline 13 & Jurnal Kelautan Nasional (Jkn) & Pusat Riset Kelautan & $\begin{array}{l}\text { ISSN 1907-767X, e- } \\
\text { ISSN 2615-4579 }\end{array}$ \\
\hline 14 & $\begin{array}{l}\text { Jurnal Sosial Ekonomi Kelautan Dan } \\
\text { Perikanan }\end{array}$ & $\begin{array}{l}\text { Balai Besar Riset Sosial } \\
\text { Ekonomi }\end{array}$ & $\begin{array}{l}\text { ISSN: } 2089-6980 \text { e- } \\
\text { ISSN: } 2527-3280\end{array}$ \\
\hline 15 & $\begin{array}{l}\text { Jurnal Kebijakan Sosial Ekonomi Kelautan } \\
\text { Dan Perikanan }\end{array}$ & $\begin{array}{l}\text { Balai Besar Riset Sosial } \\
\text { Ekonomi }\end{array}$ & $\begin{array}{l}\text { ISSN: } 2089-6980 \text { e- } \\
\text { ISSN: } 2527-3280\end{array}$ \\
\hline 16 & $\begin{array}{l}\text { Buletin Ilmiah Marina Sosial Ekonomi } \\
\text { Kelautan Dan Perikanan }\end{array}$ & $\begin{array}{l}\text { Balai Besar Riset Sosial } \\
\text { Ekonomi }\end{array}$ & $\begin{array}{l}\text { p-ISSN: } 2502-0803 \\
\text { e-ISSN: } 2541-2930\end{array}$ \\
\hline 17 & $\begin{array}{l}\text { Jurnal Kelautan Dan Perikanan Terapan } \\
\text { (Jkpt) }\end{array}$ & Sekolah Tinggi Perikanan & ISSN Online: 2654- \\
\hline 18 & Jurnal Airaha & $\begin{array}{l}\text { Politeknik Kelautan dan } \\
\text { Perikanan Sorong }\end{array}$ & ISSN: 2621-9638 \\
\hline 19 & Chanos Chanos & $\begin{array}{l}\text { Politeknik Kelautan dan } \\
\text { Perikanan }\end{array}$ & - \\
\hline 20 & Pelagicus & $\begin{array}{l}\text { Politeknik Kelautan dan } \\
\text { Perikanan Karawang }\end{array}$ & - \\
\hline 21 & Aurelia Journal & $\begin{array}{l}\text { Politeknik Kelautan dan } \\
\text { Perikanan Dumai }\end{array}$ & E-ISSN 2715-7113 \\
\hline 22 & Marlin & $\begin{array}{l}\text { Politeknik Kelautan dan } \\
\text { Perikanan Pangandaran }\end{array}$ & $\begin{array}{l}\text { P-ISSN 2716- } \\
120 X \text { dan E- } \\
\text { ISSN 2715-963 }\end{array}$ \\
\hline 23 & Buletin Jalanidhitah Sarva Jivitam & $\begin{array}{l}\text { Sekolah Tinggi Perikanan } \\
\text { Jakarta }\end{array}$ & - \\
\hline 24 & Jurnal PARI & $\begin{array}{l}\text { Badan Riset dan Sumber } \\
\text { Daya Manusia Kelautan } \\
\text { dan Perikanan }\end{array}$ & - \\
\hline
\end{tabular}

